\title{
Comparison of sporadic and familial disease amongst 580 cases of motor neuron disease
}

\author{
TING-MING LI, * EVA ALBERMAN,* MICHAEL SWASH \\ From the Department of Clinical Epidemiology, ${ }^{*}$ The London Hospital Medical College and the Department of \\ Neurology, The London Hospital, London, UK
}

SUMMARY A review of 580 hospital case notes of patients with motor neuron disease (MND) revealed 20 families in which more than one case had been reported. For 27 of the cases in these families full medical records were available, and a history of a further 37 affected family members were obtained. The cases in these 20 families are termed familial and the remainder sporadic. Parent to child transmission occurred in 16 of the 20 families of the familial cases, suggesting autosomal dominant inheritance. In three families there was involvement of siblings only, and in one family two cousins were affected. The sex ratio for the documented familial case records seen was $0 \cdot 8: 1$ $(\mathrm{M} / \mathrm{F}=12: 15)$, for the total (documented and historical) it was 1.06:1 (33:31), but in sporadic cases it was 1.6:1 (341:212) and more frequent occurrence of sensory features at presentation was reported in the familial cases (15\% in the familial cases and $5 \%$ in the sporadic cases). However, none of these differences reached statistical significance. Familial cases also differed from sporadic cases in having a younger age of onset (a mean of 52 years in the familial cases compared with 56 years in the sporadic) and in the shorter median reported duration of illness $(1 \cdot 1$ year in the familial cases 2.6 years in the sporadic). However, in only one fifth of sporadic cases was the age at onset andB death known, although this was known for 22 of the 27 familial cases, so that the data on survivap and age of onset are too incomplete to test formally.

Motor neuron disease (MND) is usually classified into three diagnostic subsets, amyotrophic lateral sclerosis, progressive muscular atrophy and progressive bulbar palsy. These definitions have been made more precise by excluding the so-called heredofamilial spinal muscular atrophies, in which the pyramidal tracts are never involved, and also the secondary neuronal diseases such as CreutzfeldtJakob disease, carcinomatous and diabetic amyotrophies and syringomyelia.

It seems that each of these clinical types of MND include familial forms ${ }^{12}$ with different patterns of inheritance. ${ }^{134}$ In some families, in which only siblings were affected, parental consanguinity has been encountered more often than expected, suggesting autosomal recessive inheritance. Autosomal dominant patterns of inheritance have also been reported. ${ }^{1256}$ However, there is still too little

Address for reprint requests: $\mathrm{Dr} \mathrm{T} \mathrm{M} \mathrm{Li}$, Department of Clinical Epidemiology, The London Hospital Medical College, London E1 2AD, UK.

Received 31 July 1987 and in final revised form 31 December 1987. Accepted 5 January 1988 information to be sure about the classification and characteristics of these inherited forms of MND.

In this paper we describe those cases with a family history found amongst 580 consecutive sets of case notes of patients with motor neuron disease in three teaching hospitals.

\section{Methods and patients}

The source of cases were medical records of all patients with MND diagnosed between 1965 and 1982 at The London Hospital; between 1970 and 1984 at the Radcliffe Infirmary, Oxford and between 1976 and 1984 at The National Hospital for Nervous Diseases, London. In these hospitals the diagnostic index was searched for cases with ICD $356 \cdot 3$ (1964-1969), 348.9 (1970-1978) and 335.2 (1977-1984) (see table 1). The diagnosis of MND was established in each case only after full in-patient investigation which usually included blood tests, radiological studies, CSF examinations and electrophysiological studies, mainly for ruling out other disease entities. In some cases results of muscle biopsy and post mortem examinations were available.

An analysis of these clinical and diagnostic procedures to test their effectiveness in distinguishing diseases reported as being MND from those reported as being multiple sclerosis, 
Table 1 Sources of the study patients

\begin{tabular}{|c|c|c|c|c|c|}
\hline & & \multicolumn{4}{|c|}{ Number of cases } \\
\hline & & $\begin{array}{l}\text { London } \\
\text { Hospital } \\
1965-1982\end{array}$ & \multicolumn{2}{|c|}{$\begin{array}{l}\text { Radcliffe } \\
\text { Infirmary } \\
\text { Oxford } \\
1970-1984\end{array}$} & $\begin{array}{l}\text { National } \\
\text { Hospital } \\
\text { Queen Square } \\
\text { 1976-1984 }\end{array}$ \\
\hline SMND & $\mathbf{M}$ & 72 & 70 & & 199 \\
\hline & & 52 & 30 & & 130 \\
\hline FMND & $\mathbf{M}$ & 1 & 1 & & 10 \\
\hline & & 3 & 3 & & 9 \\
\hline Total & $\mathbf{M}$ & 73 & 71 & & 209 \\
\hline & $\mathbf{F}$ & 55 & 33 & & 139 \\
\hline \multirow{2}{*}{\multicolumn{4}{|c|}{ London Hospital selected by ICD codes: }} & & 348 \\
\hline & & & & $\begin{array}{l}356 \\
348 \cdot 9 \\
335 \cdot 2\end{array}$ & $\begin{array}{r}1965-1967 \\
1968-1978 \\
1979-1982\end{array}$ \\
\hline \multicolumn{4}{|c|}{ Radcliffe Infirmary: } & \multicolumn{2}{|c|}{ Personal collection } \\
\hline \multicolumn{4}{|c|}{ National Hospital selected by ICD codes: } & \multicolumn{2}{|c|}{$\begin{array}{l}348 \cdot 9: 1976-1978 \\
335 \cdot 2: 1979-1984\end{array}$} \\
\hline
\end{tabular}

cervical spondylosis and stroke was carried out. ${ }^{7}$ This showed that $96 \%$ (362 out of 378 ) of cases from three hospitals could be correctly classified by the computer analysis as having MND using a discriminant analysis procedure, so that for these hospitals and conditions there was good agreement between the diagnostic criteria in use.

\section{Results}

Twenty families were identified in which two or more cases had been reported. Sixty four cases in all were referred to but full medical notes were available for only 27 (documented cases) included in the series. For the remainder (historical cases) the medical history, or very limited information, had been obtained from the propositi (table 2). Observed differences between groups were tested using chi-squared and $t$ tests as appropriate.

\section{Genetic background}

Only the $5 \%$ documented cases ( 27 out of 580 ) could be confidently regarded as familial. However, if cases described in the family histories are included the proportion increases to $10 \%$ (64 out of 617 including the historical cases).

There were 16 families of the 20 in which there was a reported involvement of a parent and her (his) children; $\mathbf{3}$ families in which involvement only of siblings was reported; and one family in whom there were two affected paternal cousins involved (table 2).

Details of the familial cases are shown in table 2, and two examples of pedigrees are illustrated in figs 1 and 2 . Family 1 has been reported previously by Hawkes $e t a l^{2}$ but the pedigree has been modified to include additional information which has become available.

\section{Clinical characteristics}

These are summarised in table 3 . The sex ratio for the documented familial cases was $0 \cdot 8: 1(\mathrm{M} / \mathrm{F}=12: 15)$, for the total familial (documented + historical) was 1.06:1) (33:31), but in sporadic cases it was $1 \cdot 6: 1$ (341:212). Familial cases were clinically atypical with a younger mean age of onset (52 years in familial MND; 56 years in sporadic MND) and a shorter median duration of illness $(1 \cdot 1$ years in familial MND; 2.6 years in sporadic MND). There was a more frequent presentation with sensory features, four familial cases out of 27 with pain and temperature disturbance in a glove and stocking distribution. This was reported in only $5 \%$ of the sporadic cases. The site of onset of the disease in the two groups was similar; in $44 \%$ of sporadic and $48 \%$ of familial cases the clinical onset was in an arm; in $37 \%$ of each the clinical onset was in a leg. In $19 \%$ of sporadic and $15 \%$ of familial cases the clinical onset was bulbar. None of these differences however reached statistical significance, although as shown below they are in agreement with previous reports.

\section{Discussion}

\section{Sex ratio}

There have been frequent reports of preponderance of male to female patients with sporadic MND, with a tendency to the opposite finding in familial cases. Sex ratios of 1.22 to 2.5 or more ${ }^{910}$ for sporadic cases, and of $1: 1^{11}$ for familial cases have been reported. A 1:1 ratio has been calculated for sporadic cases older than 65 years. ${ }^{12}$ The female preponderance of 1:0.8 in our cases of familial MND is compatible with the observation of Hawkes even after excluding the families he described. ${ }^{2}$ This difference in the sex incidence has not been explained. Both endocrine differences and differences in environmental contacts must be considered.

Past reports also suggest differences in age of onset. In one report ${ }^{13}$ the age of onset was 51 years for familial and 61 years for sporadic cases. In our series of 580 cases the mean age of onset was 52 years for familial and 56 years for sporadic cases. This difference in age of onset might reflect earlier diagnosis of familial MND in patients acquainted with the disease in their parents or siblings. However, the apparently shorter duration in such cases suggests that it is a real phenomenon.

The duration of all MND cases from onset to death is usually 3 to 5 years although it may be as brief as 1 year or as long as 15 years. ${ }^{1}$ From our data the mean survival of familial cases was only $1 \cdot 1$ years, (derived from 22 of 27 cases) while in sporadic cases it was 2.6 years, but unfortunately information was available on only 98 out of 535 cases (table 1 ). 


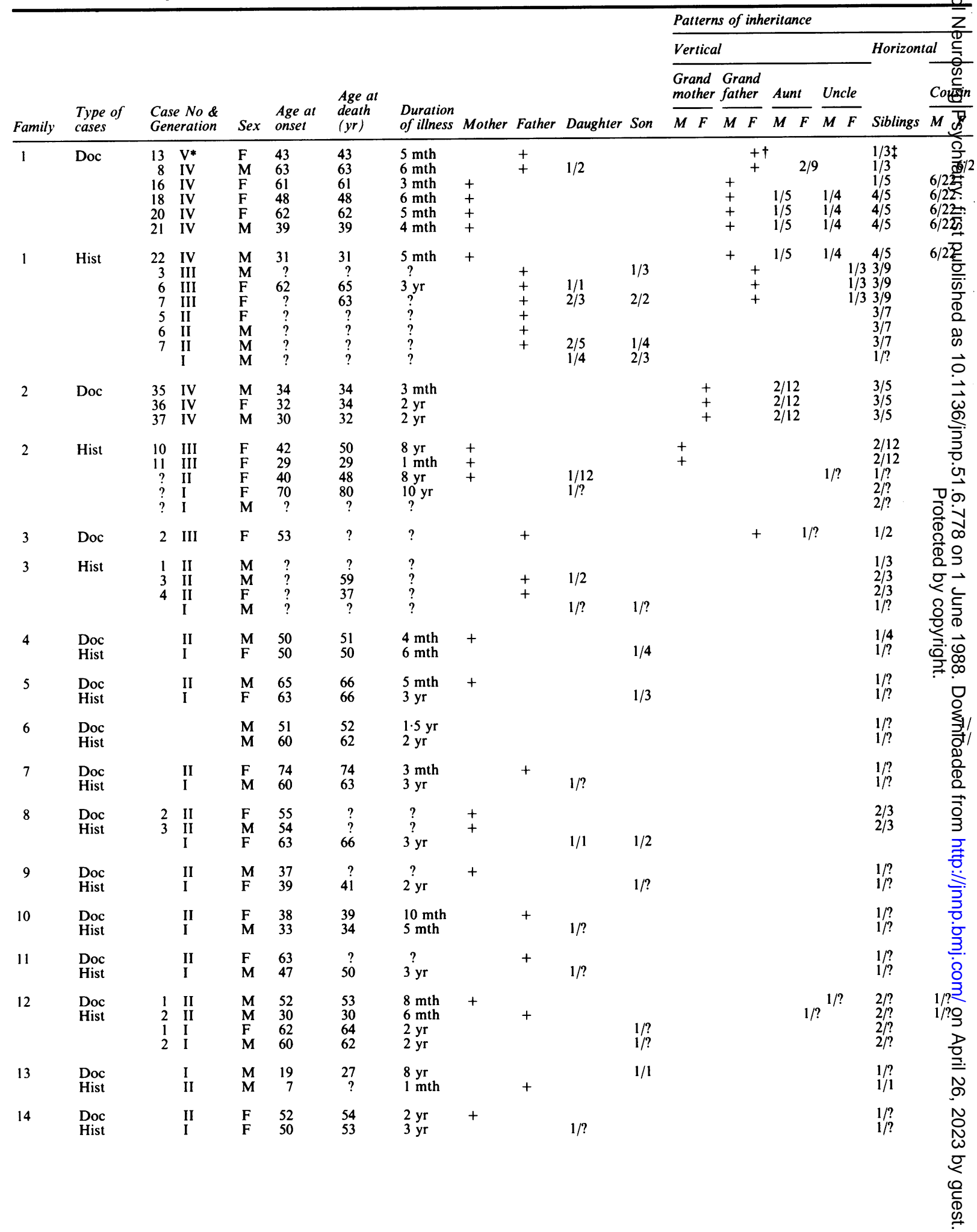




\begin{tabular}{|c|c|c|c|c|c|c|c|c|c|c|c|c|c|c|c|c|}
\hline \multirow[b]{4}{*}{ amily } & \multirow{4}{*}{$\begin{array}{l}\text { Type of } \\
\text { cases }\end{array}$} & \multirow{4}{*}{$\begin{array}{l}\text { Case No \& } \\
\text { Generation }\end{array}$} & \multirow[b]{4}{*}{$\operatorname{Sex}$} & \multirow{4}{*}{$\begin{array}{l}\text { Age at } \\
\text { onset }\end{array}$} & \multirow{4}{*}{$\begin{array}{l}\text { Age at } \\
\text { death } \\
(y r)\end{array}$} & \multirow{4}{*}{$\begin{array}{l}\text { Duration } \\
\text { of illness }\end{array}$} & \multirow[b]{4}{*}{ Mother } & \multirow[b]{4}{*}{ Father } & \multirow[b]{4}{*}{ Daughter } & \multirow[b]{4}{*}{ Son } & \multicolumn{6}{|c|}{ Patterns of inheritance } \\
\hline & & & & & & & & & & & \multicolumn{4}{|c|}{ Vertical } & \multicolumn{2}{|c|}{ Horizontal } \\
\hline & & & & & & & & & & & \multicolumn{2}{|c|}{$\begin{array}{l}\text { Grand Grand } \\
\text { mother father }\end{array}$} & Aunt & \multirow{2}{*}{$\frac{\text { Uncle }}{M F}$} & \multirow[b]{2}{*}{ Siblings } & Cousin \\
\hline & & & & & & & & & & & $\overline{M F}$ & $\overline{M F}$ & $\overline{M F}$ & & & $M F$ \\
\hline ; & $\begin{array}{l}\text { Doc } \\
\text { Hist }\end{array}$ & $\begin{array}{l}\text { II } \\
\text { I }\end{array}$ & $\begin{array}{l}\mathbf{M} \\
\mathbf{M}\end{array}$ & $\begin{array}{l}61 \\
48\end{array}$ & $\stackrel{?}{50}$ & $\stackrel{?}{2 \mathrm{yr}}$ & & & & & & & & $1 / ?$ & $\begin{array}{l}1 / ? \\
1 / ?\end{array}$ & \\
\hline ; & $\begin{array}{l}\text { Doc } \\
\text { Hist }\end{array}$ & & $\stackrel{\mathrm{F}}{\mathrm{M}}$ & $\begin{array}{l}60 \\
55\end{array}$ & $\stackrel{?}{57}$ & $\stackrel{?}{2 \mathrm{yr}}$ & & & & & & & & & $\begin{array}{l}2 / ? \\
2 / ?\end{array}$ & \\
\hline 1 & $\begin{array}{l}\text { Doc } \\
\text { Hist }\end{array}$ & $\begin{array}{l}\text { II } \\
\text { I }\end{array}$ & $\begin{array}{l}\mathbf{M} \\
\mathrm{F}\end{array}$ & $\begin{array}{l}41 \\
75\end{array}$ & $\begin{array}{l}43 \\
78\end{array}$ & $\begin{array}{l}2 \mathrm{yr} \\
5 \mathrm{yr}\end{array}$ & + & & & $1 / ?$ & & & & & $\begin{array}{l}1 / ? \\
1 / ?\end{array}$ & \\
\hline ; & $\begin{array}{l}\text { Doc } \\
\text { Hist }\end{array}$ & & $\begin{array}{l}\mathrm{F} \\
\mathbf{M}\end{array}$ & $\begin{array}{l}70 \\
54\end{array}$ & $\begin{array}{l}70 \\
54\end{array}$ & $\begin{array}{l}3 \mathrm{mth} \\
2 \mathrm{mth}\end{array}$ & & & & & & & & & $\begin{array}{l}2 / ? \\
2 / ?\end{array}$ & \\
\hline 1 & $\begin{array}{l}\text { Doc } \\
\text { Hist }\end{array}$ & $\begin{array}{l}\text { II } \\
\text { I }\end{array}$ & $\begin{array}{l}\mathrm{F} \\
\mathrm{M}\end{array}$ & $\begin{array}{l}60 \\
65\end{array}$ & $\begin{array}{l}60 \\
67\end{array}$ & $\begin{array}{l}4 \mathrm{mth} \\
2 \mathrm{yr}\end{array}$ & & + & $1 / ?$ & & & & & & $\begin{array}{l}1 / ? \\
1 / ?\end{array}$ & \\
\hline 1 & $\begin{array}{l}\text { Doc } \\
\text { Hist }\end{array}$ & & $\begin{array}{l}F \\
F\end{array}$ & $\begin{array}{l}73 \\
52\end{array}$ & $\begin{array}{l}74 \\
54\end{array}$ & $\begin{array}{l}5 \mathrm{mth} \\
2 \mathrm{yr}\end{array}$ & & & & & & & & & $\begin{array}{l}2 / ? \\
2 / ?\end{array}$ & \\
\hline
\end{tabular}

: fifth generation.

grandfather (father side) had the disease.

$1 / 3$ one of the three siblings had the disease.

$=$ case of MND.

It has been suggested that sensory pathways are more often involved in familial cases. ${ }^{2314}$. This is compatible with our finding that 4 of 20 familial cases had sensory features at presentation, whereas only $5 \%$ of sporadic cases had sensory features. Posterior column involvement is well recognised in familial MND. ${ }^{2}$ The issue of sensory features in MND is contentious in view of the possibility of a coexisting disorder such as polyneuropathy or cord compression, and since the coexistence of sensory features in a patient thought to have MND is usually held to exclude the diagnosis.

Table 3 Comparison of clinical features in sporadic and documented familial $M N D$

\begin{tabular}{|c|c|c|}
\hline & Sporadic $M N D$ & Familial $M N D$ \\
\hline $\begin{array}{l}\text { Sex ratio* } \\
M / F\end{array}$ & $\begin{array}{l}1 \cdot 6: 1 \\
(341 / 212)\end{array}$ & $\begin{array}{l}0 \cdot 8: 1 \\
(12 / 15)\end{array}$ \\
\hline $\begin{array}{l}\text { Age at onset }(y r)+\text { range: } \\
\text { Mean, (SD) }\end{array}$ & $\begin{array}{l}13-87 \\
56,(12 \cdot 4) \\
(n=535)\end{array}$ & $\begin{array}{l}19-74 \\
52,(14 \cdot 3) \\
(\mathrm{n}=27)\end{array}$ \\
\hline $\begin{array}{l}\text { Age at death }(y r) \dagger \text { range: } \\
\text { Mean, (SD) }\end{array}$ & $\begin{array}{l}33-88 \\
62 \cdot 3,(11.02) \\
(\mathrm{n}=98)\end{array}$ & $\begin{array}{l}27-84 \\
52 \cdot 4,(14 \cdot 6) \\
(\mathrm{n}=22)\end{array}$ \\
\hline $\begin{array}{l}\text { Duration of illness } \dagger(\mathrm{yr}) \\
\text { Mean, (SD) }\end{array}$ & $\begin{array}{l}2 \cdot 6,(3.09) \\
(n=98)\end{array}$ & $\begin{array}{l}1 \cdot 1,(1 \cdot 74) \\
(n=22)\end{array}$ \\
\hline $\begin{array}{l}\text { Sensory symptom* } \\
\text { and/or sign }\end{array}$ & $\begin{array}{l}5 \cdot 2 \% \\
(n=553)\end{array}$ & $\begin{array}{l}14.8 \% \\
(n=27)\end{array}$ \\
\hline $\begin{aligned} \text { Site of Onset*: } & \text { Arm } \\
& \text { Leg } \\
& \text { Bulbar }\end{aligned}$ & $\begin{array}{l}43.6 \%(241 / 553) \\
37 \cdot 3 \%(206 / 553) \\
19 \cdot 0 \%(105 / 553)\end{array}$ & $\begin{array}{l}48.1 \%(13 / 27) \\
37.0 \%(10 / 27) \\
14.8 \%(4 / 27)\end{array}$ \\
\hline
\end{tabular}

*None of the differences shown here reached statistical significance †The information was too incomplete to test.
The proportion of cases in which the presenting symptoms involved the legs in the present series is consistent with previous reports and was the same in both sporadic and familial MND. In two previous studies, the disease began with weakness in the legs in $40 \%{ }^{15}$ and $48 \%{ }^{16}$ of patients with familial MND. In our series the disease presented with weakness of the legs in $37 \%$ in both groups. In an earlier study of sporadic MND 37\% (94 out of 255) began in the legs and $28 \%$ (72 out of 255 ) began in the bulbar area. ${ }^{17}$ In the present study only $19 \%$ in the sporadic cases had a bulbar onset, and the comparable figure for familial cases was $15 \%$.

\section{Pattern of inheritance}

A major problem in genetic studies of MND is that the late age of onset of the disease makes it likely that the familial nature of many cases is not ascertained, as many of those theoretically at risk have not reached the usual age of onset at the time of reporting, ${ }^{8}$ so that it is likely that the estimate of the proportion of familial cases is always low.

In approximately $10-15 \%$ a familial occurrence of MND has been reported. ${ }^{11819}$ Based on our documented cases the proportion in the present study is $5 \%$ ( 27 out of 580 ), but if cases described in the family histories are included, the proportion increases to $10 \%$ (64 out of 617 ).

In 24 families with 124 cases of typical amyotrophic lateral sclerosis reported by Kurland and Mulder ${ }^{11}$ inheritance was autosomal dominant. In the present series parent to child transmission occurred in $80 \%$, 

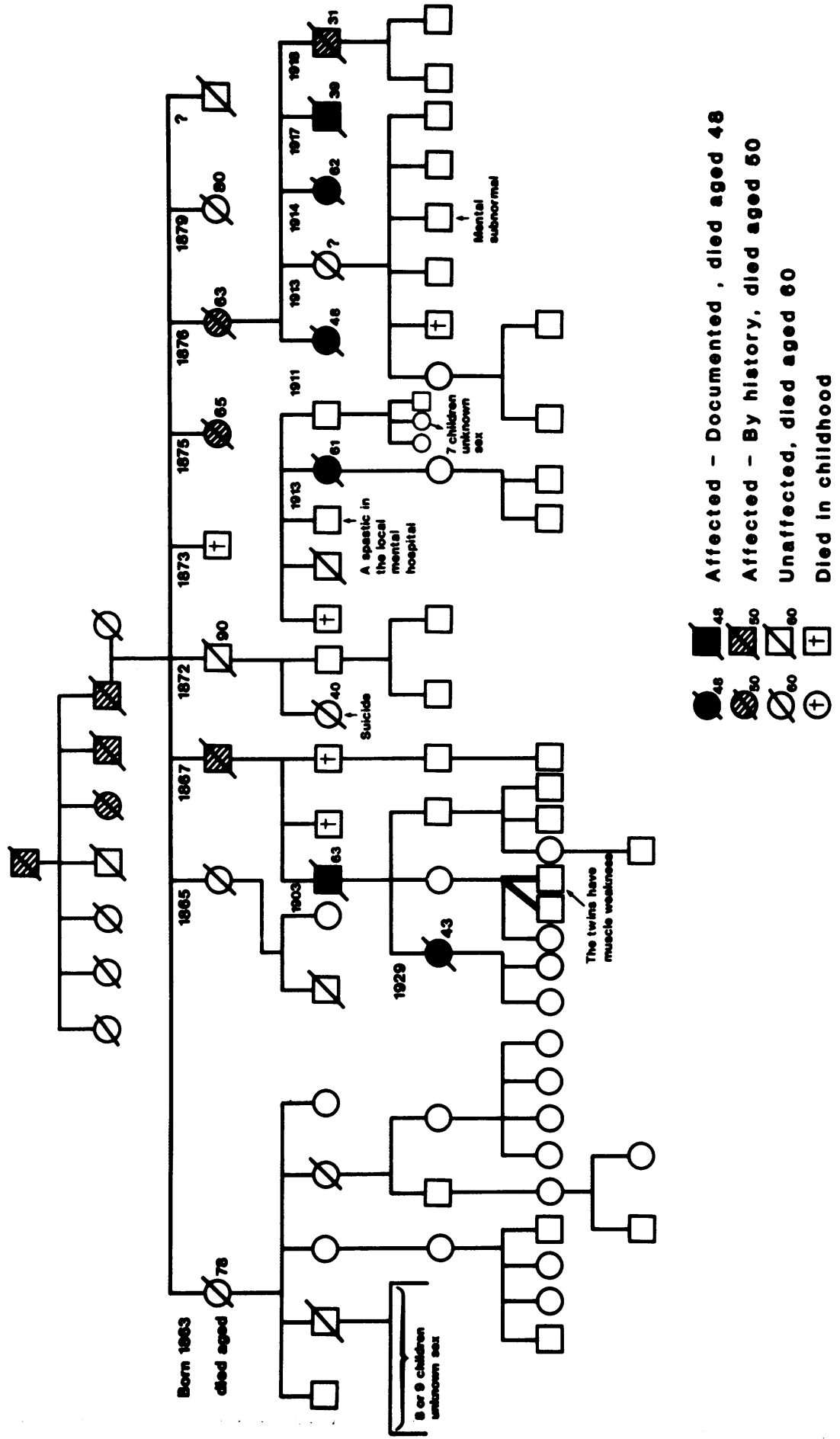


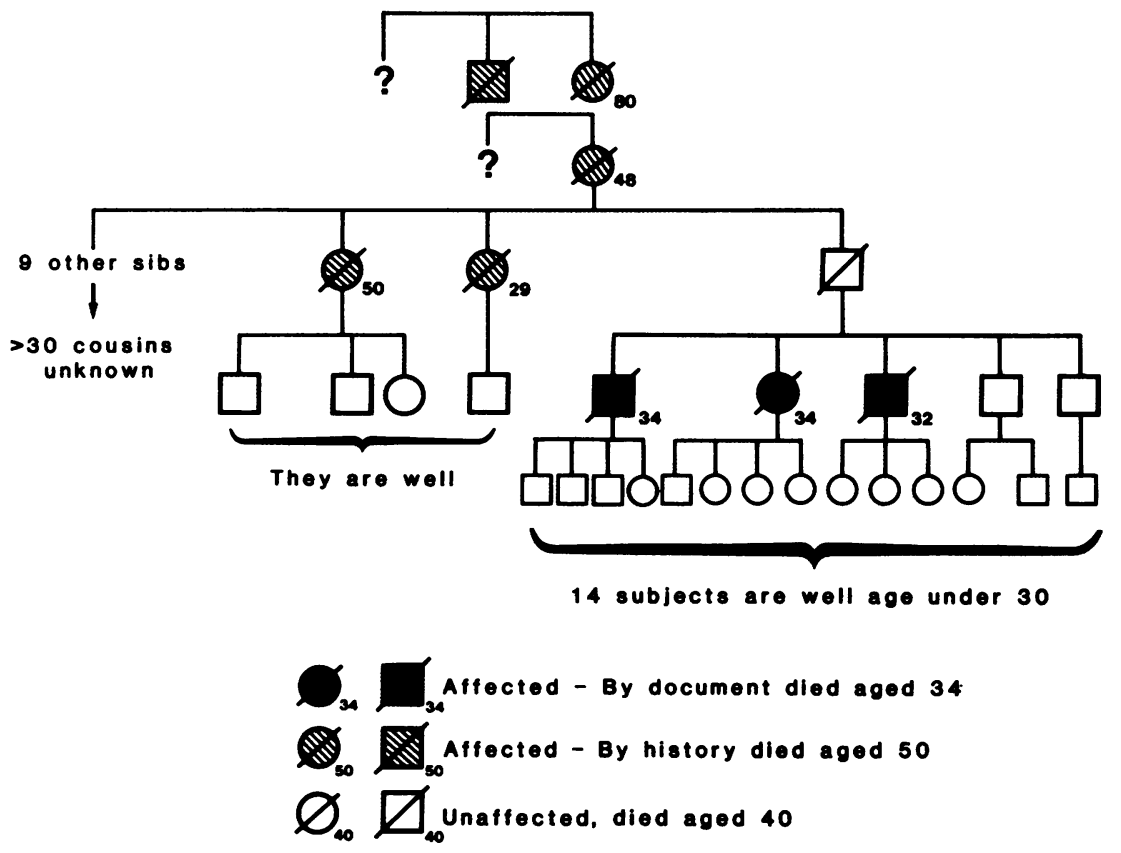

Fig 2 A pedigree of family 2.

supporting the theory of autosomal dominant inheritance. The remaining $20 \%$ of these cases probably include genetic disorders possibly inherited in an irregular dominant pattern with incomplete penetrance, but if this were the explanation then one would have to postulate a very low penetrance. However, strong familial clustering, both vertically and horizontally, does not necessarily imply a genetic mechanism. Thus vertical transmission of an infectious agent, rather than Mendelian inheritance, may explain a familial occurrence of an obscure disease. Furthermore, a genetic analysis of familial MND requires knowledge of metabolic differences between different types of neurons. Such knowledge is very limited at present. For a thorough evaluation of the genetic mechanism, the data would consist, ideally, of the complete family histories of a large group of completely ascertained index cases with a full physical examination collected from a large population. In practice, it is often impossible to ascertain every case in the community, and when retrospective anslysis of medical notes is carried out as in our study, the pedigrees are probably always incomplete, which increases the difficulty of segregation analysis for determining a particular pattern of inheritance. Twin studies ${ }^{20-23}$ have not proved helpful.

In summary, although clinical patterns of familial MND overlap with those of sporadic MND, the former appear to be more variable both clinically ${ }^{13}$ and according to the literature, pathologically, ${ }^{214}$ than sporadic cases. In familial MND the disease may begin at a younger age, and males and females are affected with the same frequency. ${ }^{11}$ The reported pathology6 1418 of the familial and sporadic forms shows slight differences, with more marked posterior column involvement, ${ }^{2}$ and loss of neurons in Clarke's column in familial than in sporadic MND. ${ }^{24}$ Although these features indicate that the two groups may differ slightly, the role of familial factors in susceptibility to MND in sporadic cases is unknown and requires further prospective investigation.

This study was supported by the Wellcome Trust and the Motor Neurone Disease Association. We thank physicians at the National Hospital for Nervous Diseases, physicians of the London Hospital, Professor Matthews and Dr Oxbury of the Radcliffe Infirmary, Oxford, and Dr Hawkes of Ipswich Hospital for allowing us to study their medical records. We also thank Dr Chaput de Saintonge for his helpful advice and criticism.

\section{References}

1 Horton WA, Eldridge R, Brody JA. Familial motor neurone disease. Evidence for at least three different types. Neurology 1976;26:460-5.

2 Hawkes CH, Cavanagh JB, Mowbray S, Paul EA. Familial motor neurone disease: report of a family with five post- 
mortem studies. In: Rose FE, ed. Research Progress in Motor Neurone Disease. London: Pitman, 1984:70-8.

3 Bobowick AR, Brody JA. Epidemiology of motor neurone disease. $N$ Eng $J$ Med 1973;288:1047-55.

4 Kennedy WR, Alter M, Sung JH. Progressive proximal spinal and bulbar muscular atrophy of late onset: a sex-linked recessive trait. Neurology 1968;18:671-80.

5 Swerts L, van-Den Bergh R. Familial ALS. A study of a family suffering from this disease for three generations. J Genet Hum 1976;24(3):247-55.

6 Takahashi H, Nakamura H, Okada E. Hereditary amyotrophic lateral sclerosis, histochemical and electron microscopic study of hyaline inclusions in motor neurones. Arch Neurol 1972;27:292-9.

7 Li TM, Day S, Alberman E, Swash M. Differential diagnosis of motor neurone disease from other neurological conditions. Lancet 1986;ii:731-3.

8 Becker PE. Humangenetik (Kurzes Handbuch). Vol 1 315-400. Leipzig. Thieme.

$9 \mathrm{Li} \mathrm{TM}$, Swash M, Alberman E. Morbidity and mortality in motor neurone disease: comparison with multiple sclerosis and parkinson's disease: age and sex specific rates and cohort analyses. J Neurol Neurosurg Psychiatry 1985;48:320-7.

10 Kurland LT, Kurtzke JF, Goldberg ID. In: Epidemiology of Neurologic and Sense Organ Disorders. Vital and Health Statistics Monographs. American Public Health Association. Cambridge, Mass: Harvard University Press, 1973:108.

11 Kurland LT, Mulder DW. Epidemiologic investigations of amyotrophic lateral sclerosis. II Familial aggregations indicative of dominant inheritance. Neurology 1955;5:182-196; 249-268.

12 Rosen AD. Amyotrophic lateral sclerosis. Arch Neurol 1978;35:638-42.
13 Kurland LT, Choi NW, Sayre GP. In: Norris FH and Kurland LT, eds. Motor Neurone Diseases. Research on Amyotrophic Lateral Sclerosis and Related Disorders. New York: Grune and Stratton, 1968;28-50.

14 Hirano A, Kurland LT, Sayre GP. Familial amyotrophic lateral sclerosis. Arch Neurol 1967;16:232-43.

15 Mulder DW. The clinical syndrome of amyotrophic lateral sclerosis. Proc Staff Meet Mayo Clin 1967;32:427-43.

16 Emery Alan EH, Holloway S. In: Lewis P Rowland, ed. Familial motor neurone disease. Human Motor Neurone Diseases. New York: Raven Press, 1982;139-145.

17 Jokelainen M. Amyotrophic lateral sclerosis in Finland. II clinical characteristics. Acta Neurol Scand 1977;56:194-204.

18 Engel WK, Kurland LT, Klatzo I. An inherited disease similar to amyotrophic lateral sclerosis with a pattern of posterior column involvement: an intermediate form? Brain 1959;82:203-20.

19 Husquinet H, Pranck G. Hereditary amyotrophic lateral sclerosis transmitted for five generations. Clin Genet 1980;18(2):109-15.

20 Dyck PJ, Lambert EH. Lower motor and primary sensory neuron disease with peronear muscular atrophy. Arch Neurol 1966;18:619-25.

21 Jokelainen M, Palo J, Lokki J. Monozygous twins discordant for ALS. Eur Neurol 1978;17(5):295-9.

22. Estrin WJ. Amyotrophic lateral sclerosis in dizygotic twins. Neurology 1977;27(7):692-4.

23 Dumon J, Macken J, de Barsy TH. Concordance for ALS in pair of dizygous twins of consanguineous parents. $\mathrm{J} \mathrm{Med}$ Genet 1971;8:113-6.

24 Swash M, Leader M, Brown A, Swettenham KW. Focal loss of anterior horn cells in the cervical cord in MND. Brain 1986;106:939-52. 